\title{
Development of Thematic Teaching Materials Integrated with Riau Malay Cultural Values for Grade Elementary Students in Pekanbaru
}

\author{
Erna Nawir ${ }^{1}$, Marhamah $^{2}$, Yulianto ${ }^{2,}$ Elpri Darta Putra ${ }^{2,}$ Hariri Waldi $^{2}$ and Sisi Adelia ${ }^{2}$ \\ ${ }^{1}$ State University of Padang \\ email: erna.nana97@gmail.com \\ ${ }^{2}$ Universitas Islam Riau \\ email: marhamahahmadhamid@gmail.com
}

\begin{abstract}
This study aims to develop thematic teaching materials integrated with Riau Malay cultural values for grade IV elementary students in Pekanbaru by using the Educational Research and Development or Educational R\&D method. The development research is carried out in 3 stages, namely: 1) the preliminary study conducted by applying a qualitative descriptive approach by distributing questionnaire and interviewing the teachers and the students in order to find out their actual needs of teaching materials 2) the development of teaching material designed and integrated with the Riau Malay cultural values, followed by expert judgment, revisions, and improvements, limited trials, as well as evaluation and improvement, 3) evaluation which includes the implementation of models created by the quasi- experimental method using the pretest-posttest control group design. The results showed that the research team designed the required teaching material in the second stage in the form of a book entitled "The 2013 Curriculum Integrated Thematic Supplement," which can be used by elementary schools in Pekanbaru.
\end{abstract}

Keywords: Book, 2013 curriculum, preservation, schools, supplements, themes.

\begin{abstract}
Abstrak
Tujuan dari penelitian ini adalah untuk mengembangkan bahan ajar yang terintegrasikan dengan nilai-nilai kebudayan Melayu pada siswa kelas IV Sekolah Dasar di Pekanbaru dengan menggunakan metode penelitian pendidikan dan pengembangan. Penelitian ini dilakukan dalam tiga tahap yaitu: 1) penelitian pendahuluan dengan menggunakan pendekatan kualitatif dengan mendistribusikan kuesioner dan melakukan interview terhadap guru dan murid untuk mengetahui kebutuhan mereka saat ini akan bahan ajar 2) pengembangan bahan ajar yang didesain dan dintegrasikan dengan nilai-nilai kebudayaan Melayu yang diikuti oleh penilaian ahli, perbaikan, uji coba terbatas. 3) evaluasi yang melibatkan penerapan model-model yang diperoleh dari metode percobaan1. quasi dengan menggunakan desain kelompok pretest dan posttest. Hasil menunjukkan bahwa desain pengembangan bahan ajar yang dibuat oleh tim peneliti pada tahap yang kedua dalam bentuk buku yang berjudul "'The 2013 Curriculum Integrated Thematic Supplement," hanya bisa digunakan oleh siswa pada jenjang pendidikan Sekolah Dasar di Pekanbaru.
\end{abstract}

Keywords: Book, 2013 curriculum, preservation, schools, supplements, themes. 


\section{INTRODUCTION}

The teaching material is a medium used to develop learning activities in the classroom. It plays an important role in creating conditions for active, innovative, creative, effective, and fun learning processes (PAIKEM). Therefore, it replaces the teacher's position in the classroom, thereby enabling students to study on their own. Furthermore, it is also a means to achieve learning objectives, which tends to be impossible without books. The achievement of learning objectives is measured by using teaching materials in the form of books to provide the right facilities to students.

However, the limitation associated with this teaching material among students, especially those in Pekanbaru, is the inability to shape their character. This is because these materials, which are usually published by the Ministry of Education, tend to measure the skills of those capable of answering few questions. Therefore, they are still categorized weak in fostering students' character (Marhamah, Ramadan, \& Putra, 2018). Furthermore, learning is only knowledge; hence, educators tend to judge their students from the cognitive condition while ignoring the psychomotor and affective aspects. Therefore, it is necessary to design teaching materials that

can help achieve these attributes by integrating the Riau Malay cultural values.

Based on planning, most teachers are less prepared to use inadequate pre-existing materials due to their lack of understanding and creativity in developing the right learning tools (Kusumawati, 2017; Puspa $\mathrm{dkk}, 2017)$.The teaching materials previously used were not in accordance with the expected objectives. However, the analysis results of the students' curriculum have shown good results. In terms of intellectual development, they are able to think more abstractly and logically, analyze an $\mathrm{d}$ solve problems with more than one solution (William, 2002). Furthermore, in terms of social and more develops the, fourth-grade elementary school students are able to work together, participate in group games, adjunct to the environment, pay attention to the interests of others, understand and follow the rules of parents and social environment, and distinguish between good and bad (Rukiyati Sugiyo \& L. Andriani Purwastuti, 2017).

According to research analysis, teaching materials without incorporating the Riau Malay cultural values tend to prevent students' character formation.

The Riau Malay cultural values integrated with the teaching material are utterance, politeness, sincerity in worship, etc. Some studies previously examined the development of teaching materials with minimal integration ommmJ the Riau Mal ay cultural value (Effendy, 2015). Therefore, this study develops thematic teaching materials integrated with the cultural values for fourth-grade elementary students in Pekanbaru.

Since the enactment of the 2013 curriculum, integrated thematic learning has been used in elementary schools to incorporate subjects into one lesson theme. Therefore, this process enables students to study the subject matter in one learning theme or activity (Wahyuni, 2016). This integrated thematic learning has characteristics, such as 1) Studentcentered, 2) Providing a direct experience for children, 3) Poor subject separation process, 4) Presenting concepts from 
various subjects, 5) Flexible, (6) Developing learning outcomes according to the interests and needs of children (Ministry of Education and Culture, 2013). An educator with high integrity is needed to achieve these characteristics to achieve predetermined educational goals. They also help develop their potential and motivate students, using the contextual learning approach, which links the material with students' real lives.

The use of this approach has been adjusted in accordance with the subject, the class situation, and conditions, facilities, infrastructure, etc. Supriyono \& Dewi (2017) stated that contextual learning is an activity that helps to promote students' ability to link the material taught, which is obtained from the knowledge owned with real situations in their lives as families and communities.

\section{STEPS OF INTEGRATED THEMATIC LEARNING BASED ON CONTEXTUAL APPROACHES}

The integrated thematic context based on a contextual approach in the language learning process that is described by referring several steps. Trianto (2013) grouped them into three steps, preparation or planning, implementation, and evaluation. The first step consists of several plans, such as mapping basic competencies, designing a network of themes, developing a syllabus, and preparing a learning implementation plan. For basic mapping competencies, the following activities are carried out: firstly, the standard and basic competencies of learning indicators are analyzed. Secondly, determine the theme by carrying out the following principles:

1) Pay attention to the environment closest to students.

2) from the easiest to the difficult, 3) simple to complex, 4) concrete to abstract, 5 ) The theme chosen needs to allow the occurrence of thought processes in students, and 6) The scope of needs to be adjusted to their age, development, interests, and abilities. Thirdly, identify, and analyze basic or standard competencies and indicators. Fourthly, theme network, and syllabus development need to be carried out to properly prepare the lesson plans.

The second step is implementation, which consists of three stages: opening or introduction, core activities, and closing or confirmation activities. Opening or introductory or exploration activities are carried out to create an initial atmosphere of learning to promote students' ability to follow the learning process properly. This opening activity is intended for heating and it is carried out by exploring children's experiences on the theme to be presented, by telling stories, singing or carrying out physical activities. Core or elaboration activities are focused on activities for developing students' reading, writing, and arithmetic skills. Presentation of learning materials is performed using a variety of strategies or methods classically performed in small groups or individually.

Furthermore, closing or confirmation activities are intended to calm and end learning by concluding the results.

Meanwhile, the assessment step is an activity to obtain various information on a regular, continuous, and comprehensive 
basis regarding the process and results of students' growth and development through learning. This activity needs an accurate assessment tool, such as written and oral tests, portfolios, and daily student development reports. Some previous studies that are relevant to this research are as follows: Research conducted by Tanjung, Daulay \& Ghafari (2018) on the development of local wisdom in English teaching materials in the form of descriptive text for 7 th -grade students at State Junior High School 1 Bilah Barat showed that the validity level of the material was in a good category.

Furthermore, Research and Development (R\&D) conducted by Armawan, Darma, \& Suyasa (2017) with the title "Development of English for Guiding Teaching Materials based on Local Wisdom" showed that the teaching material developed and level of practicality were in the very high and perfect categories.

Indah Purwanti (2017) researched the implementation of Sundanese local wisdom values in Civics as a reinforcement of student character. The case study in State Junior High School 3 of Purwakarta showed that the application oJ local wisdom values proceeded smoothly after the learning process, reflecting regionalism. Furthermore, Rahmawati Fitriana, Dyah Kusrihandayani (2017), conducted a study titled "analysis of the need for the application of folklore-based English learning in Elementary Schools in Kutai Kartanegara Regency" which showed that respondents agreed with the application. However, its use was not yet maximized. Fitriyanti et al. (2016) conducted a study titled "Develops of instructional materials based on local wisdom in social studies, "which showed that in terms of validity, practicality, and effectiveness, these local wisdom-based teaching materials were adequately applied. Some of the studies mentioned above are similar to this research. Furthermore, the integration of local wisdom values merely introduces these values, especially in the introduction and closing activities on learning. Meanwhile, the application of these values is solely dependent on the teacher's ability to deliver the learning material in class.

\section{METHODS}

This development research was carried out at the State Elementary School in Pekanbaru which is located on Delima Street, Panam, Pekanbaru, Riau Province. Data were obtained from fourth-grade elementary 500 school students, 13 teachers, and 13 experts in the field of design and Malay culture during the even semester of the 2018/2019 school year. This development research was carried out in pages, namely: 1) a preliminary study carried out by applying a qualitative descriptive approach by distributing questionnaire to teachers and students and interviewing them to find out their actual needs in teaching materials as the basis for developing the product 2) the development of teaching materials based on local wisdom of Malay cultural values, followed by expert judgment, revision, limited trials, as well as evaluations and improvements, 3) evaluations which include the implementation of models made with a quasi-experimental method such as pretestposttest control group design. This study was only carried out in the second stage, which comprises of the draft and design of 
teaching materials (Borg \&Gall)

\section{FINDING AND DISCUSSION}

The form of developing thematic teaching materials integrated with Malay cultural values for fourth-grade elementary school students in Pekanbaru is teacher and student books. It can help teachers achieve core competencies (KI) and essential competencies (KD) of learning in following the Themes oJ "My Ideals (Theme 6) (Puspa, 2017), The Beautiful of Diversity in My Country (Theme 7) (Kusumawati, 2017), and The Area oJ My Residence (Theme 8) (Subekti, 2017). These are developed into a number of Sub Themes, such as (1) Amazingly My Ideals (Sub Theme 2) integration of Social Sciences (IPS) and Cultural Arts and Crafts (SBdP) subjects, (2) Enterprisingly Trying to Achieve Ideals (Sub Theme 3) integration of Cultural Arts and Craft subjects (SBd P), (3) The Beautiful of Cultural Diversion in My Country (Sub Theme 2) integration of IPS, SBd P and Pancasila and Citizenship (PPKn) subjects, (4) The Beauty of My Country's Unit (Sub Theme 3) integration of Indonesian Language subjects (BI) and SBd P, (S) The Environment of My Residence (Sub

\section{- Model Borg and Gall}

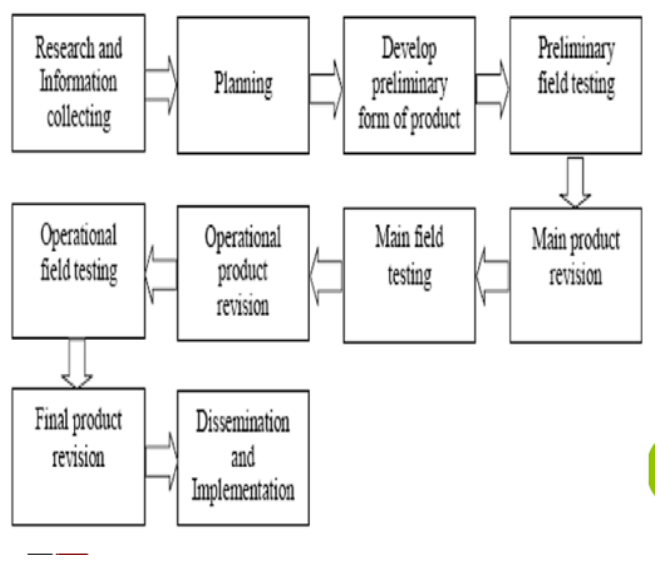

Theme 1) integration of BI, Natural Sciences (IPA) subjects, (6) The Uniqueness of My Residence Area (Sub Theme 2) integration of $\mathrm{BI}$ and $\mathrm{SBd} \mathrm{P}$ subjects, and (7) Proud of My Residence Area (Sub Theme 3) integration of BI subjects.

This teaching material has the following special characteristics:

\section{Description of BMR- Based Teaching Material Display}

Organization: (1) displays a concept map that shows the integration of several exiting subjects, (2) organizes the contents of learning material in a systematic order to facilitate students, (3) arrange texts and images, (4) the organization of learning activities and the description of material easily followed by students.

Attractiveness: (1) the front cover uses matching colors, images, and letter shapes, (2) the contents of teaching materials place stimuli in the form of concrete images, or text written in bold and italic font, with appropriate and attractive colors, (3) learning activities, exercises and assignments are made interesting to motivate students in completing these tasks.

Letters: (1) use shapes and letters that are easy to read and according to Grade IV Elementary School students' characteristics. This teaching material uses Times News Roman font with size 12, (2) uses different font apes between the title and contents of the script.

\section{Page Structuring and Numbering System}

This product is printed on 80 -gram A4 paper because it is full of color. Page numbering uses Times New Roman font.

\section{Space (Blank Space)}

This product need $\mathrm{s}$ to use blank spaces around titles, margin $\mathrm{s}$, and turnover 
between paragraphs, pages need to be added as an additional important note for students.

\section{Consistency}

Consistency in using shapes, letters, spacing, and typing layout.

\section{Language Description}

The language used is suitable for users of this teaching material by considering their intellectual, social, and emotional development. These need to be accurate and straightforward, with the ability to communicative directly with the reader.

\section{Content Description}

The product descriptions of these BMRbased teaching materials arE introduction,

(2) learning activities, and (3) closing as follows.

\section{Introduction}

The introduction consists of a preface, description of teaching materials, time allocation, prerequisites, and instruction $\mathrm{s}$ for the use of teaching materials.

\section{Learning Activities}

This is used to briefly describe the material's points and activities in some exercises that are in accordance with the implementation of the 2013 curriculum, through texts and image for better understanding.

Closing

This section contains references and author profile.

\section{Steps of Textbook Development}

The steps of textbook development are as follows:

\section{Planning}

In this stage, planning is conducted by identifying Core Competencies (KI) and Basic Competencies (KD), developing Riau Malay culture-based indicators, formulating goals, determining learning methods, and formulating assessments. Furthermore, the studies are limited to the materials related to the elements of Riau Malay culture, such as Songs, Figures (heroes), Musical Instruments, Dances, traditional Houses, Marks and historical relics of Riau that set out in themes 6, 7 and 8 as follows:

\section{Identifying $\mathrm{KI}$ and $\mathrm{KD}$}

In this stage, the identification of KI and $\mathrm{KD}$ of each subject is carried out and used as a guideline for developing indicators of integrated thematic teaching materials. The KI and KD of subjects identified include learning of PPKn, Indonesian Language, Mathematics, Natural Sciences, Social Studies, SB\&P, and PJOK for class IV limited to themes 6, 7 and 8 which are shown as follows:

KI 1 : Accept practice the teachings of the religion

KI 2 : Have honest behavior, discipline, responsible, polite, caring and confident in interacting with family, friend $s$, teachers, and neighbors

KI 3 : Understand factual knowledge by listening, seeing, reading and asking questions based and curiosity regarding God's creatures and their activities in homes and schools

KI 4 : Present factual knowledge in a clear, systematic and logical language that reflect healthy children with faith and noble characters.

Table 4.1: Identification oJ KI and KD of Pancasila and Citizenship Education (PPKn) Subjects

(Source: Ministry of Education and Culture (2016))

Basic competencies 


\section{K11}

1.3 Grateful Jor the diversity of religious communities in the socie as a gift from God Almighty in the context of Bhineka Tunggal Ika (Unit in Diversion)

\section{$\mathrm{KI} 2$}

2.3 Be tolerant in the diversity of religious communities in the context of Unit in
Diversion The Basic Competencies (KD) is limited to the subjects of Social Sciences (I PS), Cultural Arts and Crafts (SBd P), Pancasila and Citizenship Education (PPKn), Indonesian language, and Natural Sciences (IPA) which are explained in table

Table 1: Identification of KI and KD (Source: Ministry of Education and Culture (2016b) below:

\begin{tabular}{|l|l|}
\hline Subjects & Basic Competencies \\
\hline SBd P & $\begin{array}{l}\text { Identifying the motion of region al modified } \\
\text { dance } \\
\text { Recognizing fine artworks with paste } \\
\text { techniques } \\
\text { Demonstrating the motion of regional modified dance } \\
\text { Making collage, montage, application, and } \\
\text { mosaic works }\end{array}$ \\
\hline IPS & $\begin{array}{l}\text { 3.2 Recognizing social, economic, cultural, ethnic and religious diversity in the local province } \\
\text { as the Indonesian nation's identity and its relationship to space characteristics (Riau } \\
\text { Traditional House) }\end{array}$ \\
\hline PPKn & $\begin{array}{l}\text { 3.4 Identifying various forms of ethnic, nation al, social and cultural diversion in Indonesia } \\
\text { related to } \\
\text { unity (Traditional House) }\end{array}$ \\
\hline BI & $\begin{array}{l}\text { 3.7 Exploring new knowledge contained in } \\
\text { nonfiction text (Report Text) } \\
\text { 3.9 Paying close attention to the characters contained in fiction texts (Riau Folklore) } \\
4.7 \text { Conveying new knowledge from nonfiction texts into writing in their own language } \\
4.9 \text { Conveying the characters contained in the fiction text verbally, written and visually. }\end{array}$ \\
\hline IPA & $\begin{array}{l}\text { 3.4Connecting forcewithamotiontothe events } \\
\text { in the surrounding environment } \\
4.4 \text { Presenting experimental results on the } \\
\text { relationship between force and motion }\end{array}$ \\
\hline
\end{tabular}

a. Development of Learning Indicators

The purpose of developing this indicator was to identify the initial abilities needed by students to achieve the general objectives. The indicators were developed by looking at keywords in basic competencies of five subjects, namely Sbd $\mathrm{P}$ with four basic competencies, IPS with
1 basic competence, PPKN with 1 basic competence, BI with its 4 basic competencies, and IPA with its two basic competences. Those basic competences of each subject are described in more detail in Table 4.3. 
Table 2: Development of cultural indicators based on Riau Malay culture

\begin{tabular}{|c|c|c|c|c|}
\hline \multirow[t]{2}{*}{ Subject } & \multirow[t]{2}{*}{ Basic Competencies } & & Indicator & \\
\hline & & Cognitive & Affective & Psychomotor \\
\hline SBd P & $\begin{array}{l}\text { 1. Identifying the motion of regional } \\
\text { modified dance. } \\
\text { 2. Recognizing fine artworks with paste } \\
\text { techniques. } \\
\text { 3. Demonstrating the motion of } \\
\text { regional modified dance. } \\
\text { 4. Making collage, montage, } \\
\text { application, and mosaic works }\end{array}$ & $\begin{array}{l}\text { Mentioning } \\
\text { dances, fine } \\
\text { artworks } \\
\text { (sculpture) in } \\
\text { Riau }\end{array}$ & $\begin{array}{l}\text { Showing gratitude } \\
\text { and pride in God's } \\
\text { favor for the } \\
\text { diversion of Riau's } \\
\text { culture }\end{array}$ & $\begin{array}{l}\text { Showing } \\
\text { gratitude and } \\
\text { pride in God's } \\
\text { favor for the } \\
\text { diversion of } \\
\text { Riau's culture }\end{array}$ \\
\hline IPS & $\begin{array}{l}\text { Recognizing social, economic, } \\
\text { cultural, ethnic and religious } \\
\text { diversity in the local province as the } \\
\text { Indonesian nation's identity and its } \\
\text { relationship to space characteristics } \\
\text { (Riau Traditional House) }\end{array}$ & $\begin{array}{l}\text { Mentioning } \\
\text { traditional } \\
\text { houses in Riau }\end{array}$ & & $\begin{array}{l}\text { Making a } \\
\text { replica of a } \\
\text { traditional } \\
\text { house in Riau }\end{array}$ \\
\hline PPKN & $\begin{array}{l}\text { Identifying various forms of ethnic, } \\
\text { national, social, and cultural } \\
\text { diversity. }\end{array}$ & $\begin{array}{l}\text { Mentioning } \\
\text { traditional } \\
\text { houses in Riau }\end{array}$ & & \\
\hline BI & $\begin{array}{l}\text { 3.7 Exploring new knowledge contained } \\
\text { in nonfiction text (Report Text) } \\
\text { 3.9 Paying close attention to the } \\
\text { characters contained in fiction texts } \\
\text { (Riau Folklore) } \\
\text { 4.7 Conveying new knowledge from } \\
\text { nonfiction texts into writing } \\
4.9 \text { Conveying the identified results of } \\
\text { the characters contained in the } \\
\text { fiction text verbally, written and } \\
\text { visual }\end{array}$ & $\begin{array}{l}\text { Identifying } \\
\text { meanings, } \\
\text { characters from } \\
\text { the story read }\end{array}$ & & $\begin{array}{l}\text { Reading out } \\
\text { loud }\end{array}$ \\
\hline IPA & $\begin{array}{l}\text { - Connecting force with a motion to } \\
\text { the events in the surroundings } \\
\text { environment } \\
\text { - Presenting experimental results on } \\
\text { the relationship between force and } \\
\text { motion }\end{array}$ & & & \\
\hline
\end{tabular}


Based on the table above, it can be noticed that each subject has its own competence or competences. The basic competences are formulated by considering three domains of the students' which are cognitive domain, affective domain and psychomotor domain.

b. Formulation of Learning Objectives and Methods

The purpose of this formulation was to identify the goals that need to be achieved by students in learning, based on previously mentioned indicators. These abilities and behaviors were specifically formulated and operationalized, using tests or other measuring instruments. The formulation of competency achievement indicators were used as a basis for developing the learning test grid. Meanwhile, the method acts as a teacherguide in class management. The choice of method was adjusted to the needs, subject matter, and interests of students, as shown in Table 4.4:

Table 3: Formulation of Learning Objectives and Methods

\begin{tabular}{|c|c|c|c|c|c|}
\hline \multirow[t]{2}{*}{ Subjects } & \multicolumn{3}{|c|}{ Indicator } & \multirow{2}{*}{$\begin{array}{l}\text { Learning } \\
\text { objective }\end{array}$} & \multirow[t]{2}{*}{ Learning Methods } \\
\hline & Cognitive & Affective & Psychomotor & & \\
\hline $\begin{array}{l}\text { SBdP, I PS, } \\
\text { PPKn, BI, I PA }\end{array}$ & $\begin{array}{c}\text { Mentioning } \\
\text { dances, works of } \\
\text { fine arts statues, } \\
\text { traditional houses, } \\
\text { characters in } \\
\text { folkfore and } \\
\text { dance motions in } \\
\text { Riau }\end{array}$ & $\begin{array}{l}\text { Showing } \\
\text { gratitude and pride } \\
\text { for the diversity in } \\
\text { Riau of Riau's } \\
\text { Culture }\end{array}$ & $\begin{array}{l}\text { Making line } \\
\text { artworks, playing } \\
\text { roles, performing } \\
\text { Riau dance } \\
\text { motions }\end{array}$ & $\begin{array}{l}\text { 1.Exploration } \\
\text { enables students } \\
\text { to mention } \\
\text { crafts, } \\
\text { traditional } \\
\text { houses, } \\
\text { sculpture, } \\
\text { characters in } \\
\text { stories and } \\
\text { dance motions } \\
\text { in Riau. }\end{array}$ & $\begin{array}{l}\text { Discussion } \\
\text { and Question and } \\
\text { answer } \\
\text { Role Playing and } \\
\text { direct practice, } \\
\text { checking list, rating } \\
\text { or scales }\end{array}$ \\
\hline & & & & $\begin{array}{l}\text { 2.By } \\
\text { recognizing } \\
\text { the diversity of } \\
\text { local culture in } \\
\text { Riau, they are } \\
\text { able to foster } \\
\text { gratitude and } \\
\text { pride. } \\
\text { 3.Students are } \\
\text { able to make } \\
\text { sculpture, } \\
\text { drawing } \\
\text { traditional } \\
\text { houses, play } \\
\text { roles } \\
\text { characters in } \\
\text { stories, and }\end{array}$ & \\
\hline
\end{tabular}




\begin{tabular}{|l|l|l|l|l|}
\hline & & & $\begin{array}{l}\text { perform Riau } \\
\text { dances and } \\
\text { though direct } \\
\text { practices }\end{array}$ \\
\hline
\end{tabular}

As can be seen from table 4.4 that learning objectives of all the subjects are formulated based on the indicators of the three domains expected from the students, namely affective, cognitive and psychomotor domain, therefore the learning methods are adjusted and to be implemented based on the indicators as well. c. Formulation of Assessment

The formulation of the assessment was based on indicators, such as the assessment of attitude, knowledge, and skills, as shown in Table 4.5 (Kurniawan\&Noviana, 2017).

Table 4: Formulation of Assessment

\begin{tabular}{|c|c|c|c|c|c|c|}
\hline \multirow[b]{2}{*}{ Subjects } & \multicolumn{3}{|c|}{ Indicator } & \multirow{2}{*}{$\begin{array}{l}\text { Learning } \\
\text { objectives }\end{array}$} & \multicolumn{2}{|c|}{ Assessment } \\
\hline & Cognitive & Affective & Psychomotor & & $\begin{array}{c}\text { Assessment } \\
\text { Technique }\end{array}$ & Instrument \\
\hline $\begin{array}{l}\text { SBdP, IPS, } \\
\text { PPKN, BI, IPA }\end{array}$ & $\begin{array}{l}\text { Mentioning, } \\
\text { dances, works } \\
\text { of fine arts } \\
\text { (statues). } \\
\text { Traditional } \\
\text { houses, } \\
\text { character in } \\
\text { folkfore and } \\
\text { dance and } \\
\text { motion in Riau }\end{array}$ & $\begin{array}{l}\text { Showing } \\
\text { gratitude and } \\
\text { pride in God's } \\
\text { diversity of } \\
\text { Riau's culture }\end{array}$ & $\begin{array}{l}\text { Making fine } \\
\text { art works, } \\
\text { playing roles } \\
\text { and } \\
\text { performing } \\
\text { Riau dance and } \\
\text { motions }\end{array}$ & $\begin{array}{l}\text { 1.Exploration } \\
\text { enables } \\
\text { students to } \\
\text { mention crafts, } \\
\text { traditional } \\
\text { houses, } \\
\text { sculptures, } \\
\text { characters in } \\
\text { stories, and } \\
\text { dance motions } \\
\text { in Riau }\end{array}$ & $\begin{array}{l}\text { Writing test, } \\
\text { self- } \\
\text { assessment, } \\
\text { portfolio }\end{array}$ & $\begin{array}{l}\text { Multiple } \\
\text { choice, } \\
\text { questions and } \\
\text { essays, check } \\
\text { list/rating/scale }\end{array}$ \\
\hline & & & & $\begin{array}{l}\text { 2.By } \\
\text { recognizing the } \\
\text { diversity of } \\
\text { local culture in } \\
\text { Riau, they are } \\
\text { able to foster } \\
\text { gratitude and } \\
\text { pride } \\
\text { 3.Students are } \\
\text { able to make } \\
\text { sculptures, draw } \\
\text { traditional } \\
\text { houses, play }\end{array}$ & & \\
\hline
\end{tabular}




\begin{tabular}{|l|l|l|l|l|}
\hline & & & $\begin{array}{l}\text { roles as } \\
\text { characters in } \\
\text { stories, and } \\
\text { perform dances } \\
\text { through direct } \\
\text { practice }\end{array}$ & \\
& & & \\
\hline
\end{tabular}

As can be seen from table 4.5, the assessment technique and the instruments used are employed based on the learning objective formulated previously. The objectives which are going to be achieved to improve students' cognitive, affective and psychomotor domain of the students in all subjects. The reason is to make sure that students' competences can be measured appropriately.

Although the designed textbook was interesting and educating, it has not been tested on students and teachers. This book has the content or theme of teaching materials that have fulfilled the development characteristics of grade IV elementary school students in accordance with the Riau Malay Cultural Values. This is in line with the opinion of Dick, Carey, \& James O (2014) on the selection of teaching materials; such as (1) interesting enough (2) right contents, (3) correct order, (4) needed information is available, (5) practical questions, (6) answers to the exercise, (7) instructions for students, and (8) clear training instructions.

Furthermore, this textbook has been developed based on conformity with the predetermined objectives, as formulated in the curriculum this is because the purpose of packaging learning materials is directed achieve maximum goals, in terms of general behavioral change, and learning outcome indicators (Law No. 20 of 2003 on the National Education System, 2003).

\section{CONCLUSIONS}

In conclusion, thematic teaching materials based on Malay cultural values for fourthgrade elementary school students in this study are in the form of textbooks. The material is arranged based on the mapping of basic and core competencies for class IV students. Also, the textbook has several activities. For the pedagogical implication, it is highly recommended to every teacher to adjust students' need with students' real need of learning in order to keep their learning motivation. Creativity is one of the most important competences that a teacher should have in teaching, and for other teachers and researchers who would like develop another teaching material, it is important to keep themselves on updating information of students' learning need due to dynamic change of learning condition. 


\section{REFERENCES}

Armawan, I. K., Darma, M., \& Suyasa, S. (2017). Pengembangan Materi Ajar English for Guiding Berbasis Kearifan lokal.796-802.

Dick, W., Carey, L., \& James O, C. (Z014). The Systematic Design of Instruction 8th Edition. Pearson Education, Inc.

Hendy, T. (2015). Tunjuk Ajar Melayu. Pekanbaru: Dinas Pendidikan dan Kebudayaan Provinsi Riau bekerjasama dengan Tenas Effendy.

Fitriyanti dkk. (2016). Development of InstructionaI Materials Based on Local Wisdom in Social Studies.

Proceedings of the 2nd SULE - IC 2016, FKIP, Unsur( Po/e/rtbong October 7th-9th ， 2016, 395-408. Kemendikbud. (2016). Permendikbud No. 2 / 7o/iun 2016 - Standar Isi Pendidikan Dasar dan Menengah. Kurniaman, O., \& Noviana, E. (2017). Penerapan Kurikulum 2013 dalam Meningkatkan Keterampilan, Sikap, dan Pengetahuan. Primary. Jurnal Pendidikan Guru Sekolah Dasar, 6(2), 389. https://doi.org/10.33 578/jpfkip.v6iZ.45Z0

Kusumawati, H. (2017). Indahnya Keragaman di Negeriku Buku Tematik Terpadu Kurikulum 2013 Buku Siswa SD/MI kelas IV.

Marhamah, Ramadan, Z. H., \& Putra, E. D. (2018). JAI PTEKIN | Jurnal Aplikasi IPTEK Indonesia Pengembangan Bahan Ajar Tematik Berbasis Nilai-Nilai Budaya Melayu Di Sekolah Dasar. Jurnal Aplikasi lP YES Indonesia, 4AIP TEKIN, $£(3)$, $29-33$.
Borg, R, W \& Gall, D. (2003). Educational Research. New York: Longman

Metty Indah Purwanti, S. I. (2017). Implementasi Nilai-Nilai Kearifan Lokal Sunda Dalam Pembelajaran P KN sebagai Penguat Karakter Siswa (Studi Kasus di SMPN 3 Purwakarta). JPIS. Jurnal Pendidikan llmu Sosial 26(1), 39-52. Retrieved from Mettypurwanti.iboabo@gmail.com

Puspa, D. dkk. (2017). Tematik Terpadu Kurikulum 2013 untuk SD/MI Kelas IV.

Rahmawati Fitriana, Dyah Kusrihandayani, F. (2017). Need Analysis on The Applying English Learning Based o Folktale of Kutai Kartanegara at Elemantary School banyak meninggalkan cerita - cerita rakyat Legenda Perayaan Erau Naga, Putri Karang membantu menjaga dan melestarikan dan melestarikan kearifan. SNITT -Politeknik Negeri Bolik Papon.

Rukiyati Sugiya, \& L. Andriani Purwastuti. (2017). Local WisdomBased Character Education Model in Elementary School in Bantul Yogyakarta Indonesia. Sino -US English Teaching, 74(5). https://doi.org/10.17Z65/1539807Z/2017.05.003

Subekti, A. (Z017). Tematik Terpadu Kurikulum 2013 untuk SD 7 MI Kelas IV.

Supriyono, Y., \& Dewi, N. S. N. (Z017). English Language Immersion Berbasis Kearifan Lokal Bagi Siswa 
Sekolah Dasar. Sarwahita, 4(02), 140144.

https://doi.org/10.21009/sarwahita.14 Z.08

Tanjung, P., Daulay, S., \& Ghafari, O. F. (2018). The Development of Local Wisdom of Labuhan Batu Based on Teaching Material of Descriptive Text of 7th Grade Student at SMP Negeri 1 Bilah Barat, Indonesia. International Journal of Education, Learning and Development, 6(1), $80-92$.

Trianto. (2013). Desain Pengembangan Pembelajaran Tematik bagi Anak Usia Dini TK/RA \& Anak Usia

Kelas Awal SD/MI. Jakarta: PT Fajar
Interpratama Mandiri.

UU No. 20 Tahun 2003 tentang Sistem Pendidikan Nasional. (2003). https://doi.org/10.16309/j.cnki.issn.100 7-1776.2003.03.004

Wahyuni, S. (2016). Curriculum Development in Indonesian Context the Historical Perspectives and the Implementation. Universum, $\operatorname{ID}(1)$. https://doi.org/10.30762/universum.v $10 \mathrm{i} 1.225$

William s, M. (2002). Teaching Languages to Young Learners. L. Cameron. ELT Journal, 56(2), 201203 